\title{
Evaluation of Concentration of some Heavy Metals in Water, Soil, and Fish from Ponds in Lugbe, Idu and Kuje in the Federal Capital Territory (FCT), Abuja, Nigeria.
}

\author{
Modupe Munirat Adeyemi ${ }^{1}$, Indi Ambi $\mathrm{Ugah}^{2}$ \\ ${ }^{1,2}$ (Department of Chemistry, Nigerian Defence Academy, Kaduna, Nigeria)
}

\begin{abstract}
Concentration of some heavy metals cadmium $(\mathrm{Cd})$ iron( $\mathrm{Fe})$ copper $(\mathrm{Cu})$, lead $(\mathrm{Pb})$, nickel (Ni) and zinc (Zn)) in water, soil and their accumulation in the edible tissue of Catfish (Clarias gariepinus), were determined in samples collected from Lugbe, Idu and Kuje in the Federal capital City, Abuja, Nigeria using flame Atomic Absorption Spectroscopy. Some physico-chemical parameters of the water samples were determined to assess the suitability for fish production. The results for heavy metals contamination revealed the concentrations in the fish samples at the different locations are in the order: Lubge - $\mathrm{Ni}>\mathrm{Zn}>\mathrm{Fe}>\mathrm{Cu}>\mathrm{Pb}>\mathrm{Cd}$; Idu $\mathrm{Cu}>\mathrm{Fe}>\mathrm{Zn}>\mathrm{Pb}>\mathrm{Ni}>\mathrm{Cd}$ and Kuje - $\mathrm{Fe}>\mathrm{Zn}>\mathrm{Pb}>\mathrm{Ni}>\mathrm{Cu}>\mathrm{Cu}$. The samples from the all the ponds showed significant variation (at $p<0.01$ ) with strong correlations in the levels of concentration of the heavy metals across the samples as a result of the human activities around the ponds. The concentrations of all the metals analyzed in fish samples in this study were below the recommended limit of FAO/WHO for human consumption; however there is need for regular monitoring of the heavy metal load in these ponds to guard against long term effects of its presence in the water which may influence the uptake by fish and humans after consumption.
\end{abstract}

Keywords: fish, heavy metals, soil, water.

\section{Introduction}

Fish consumption in Nigeria stands at about 1.5 million metric tons per annum ${ }^{[1]}$. The high demand for fish has resulted in the increase in the number of fish ponds in Abuja. Individual farmers, organised groups and institutions have developed, constructed fish ponds and started fish farming oblivious of the cost. Due to lack of proper expertise and poor management, most farmers carry out fish farming in non-standard environment ${ }^{[2]}$. Most of the farmers use large quantities of untreated waste water discharged from domestic effluents, construction sites, mining sites and other industrial sources ${ }^{[2]}$. Most of these sources of water are highly contaminated with heavy metals which interfere with the general productivity of fish ${ }^{[3]}$.Local feeds used in feeding fish may be contaminated in store, during processing, mixing or transportation as a result of spoilage or contact with non-agricultural materials being carried in the same compartment, which can create the tendency of heavy metals contaminants to accumulate to toxic concentrations in fish and its habitat and may pose as a potential health risk to humans when consumed. Poor construction and maintenance of the ponds has also resulted to unconducive physico-chemical properties of the water thereby interfering with productivity. Lack of knowledge on good hygiene practices has also directly contributed to the degradation of fish ponds water quality for habitats thereby resulting to death of fish. Some of the harvested fish from this habitat are small in size, an indicator of stunted growth. According to ${ }^{[4]}$ it is expected that the $\mathrm{pH}$, total alkalinity, electrical conductivity and hardness as well as other physico-chemical parameters lie within acceptable ranges that would support fish productivity. The Heavy metals of serious concern with respect to human health, derived from agro-chemical and industrial wastes are $\mathrm{Cd}, \mathrm{Cu}, \mathrm{Fe}, \mathrm{Pb}, \mathrm{Ni}, \mathrm{Zn}$, and $\mathrm{Hg}{ }^{[5]}$.These pollutants are capable of being biomagnified in the aquatic food chain/web and bioaccumulated in high concentrations in fish tissues to the detriment of fish consumers. Since Lugbe, Idu and Kuje are hubs for fish farming, this study was carried out to determine the concentrations of $\mathrm{Fe}, \mathrm{Zn}, \mathrm{Cd}, \mathrm{Cu}, \mathrm{Pb}$ and $\mathrm{Ni}$ in water, soil and fish (clarias gariepinus) samples from the fish ponds in those areas and the results were compared with acceptable standards. A correlation of the heavy metal concentrations between the different samples was made to evaluate the sources of contamination.

\subsection{Heavy Metals}

Heavy metals have a large effect on the environment and cause many health risks for humans. When heavy metals accumulate to toxic levels, they can cause illness in humans ${ }^{[6]}$. An assessment of heavy metal pollution in surface water in Ganga river, the most sacred and important river of India has been performed and in the midst of the inorganic contaminants of the river water, heavy metals were becoming more critical and often accumulate through tropic levels causing deleterious biological effects ${ }^{[7]}$.These heavy metals are from anthropogenic activities like mining, disposal of treated anduntreated waste effluents containing toxic metals as well as metal chelates, from different industries such as tanneries, steel plants, battery industries, thermal power 
plants, and also from the indiscriminate use of heavy metal containing agricultural fertilizers and pesticides. Several of the metals such as $\mathrm{Cu}, \mathrm{Fe}, \mathrm{Mn}, \mathrm{Ni}$, and $\mathrm{Zn}$ are essential micronutrients for life processes in living organisms. However, heavy metals like $\mathrm{Cd}, \mathrm{Cr}$, and $\mathrm{Pb}$ do not have any physiological activity but have been proven to be detrimental when their concentrations exceed a certain limit. These heavy metals are linked to deadly diseases such as edema of eyelids, tumor, congestion of nasal mucous membranes and pharynx, stuffiness of the head, and disorders of the gastrointestinal tract. Muscular, reproductive, neurological, and genetic malfunctions have also been reported to have occurred from accumulation of some of these heavy metals. Thus, determining or monitoring the concentration of these metals is imperative for safety assessment of the environment and human health in particular.

\subsection{Correlation between Aquatic Life and Heavy Metals}

Fish are at the top of the aquatic food chain and therefore, are more likely to accumulate large amounts of heavy metals from the water ${ }^{[8]}$. Fish are used in fresh waters as the major indicator for estimating the amount of trace metals referred to as pollution ${ }^{[9]}$. When these fish are consumed, they pose a potential health hazards in humans. Various organs in fish absorb heavy metals due to their affinity for them, this result in fish concentrating metals at different levels in various organs of the fish. The process made it imperative to determine the concentrations of heavy metals $(\mathrm{Cd}, \mathrm{Cu}, \mathrm{Fe}, \mathrm{Pb}, \mathrm{Ni}, \mathrm{Hg}$ and $\mathrm{Zn})$ in fish population from different water bodies as possible risk of fish consumption with heavy metals from these water sources exists.

\subsection{Aim of study}

To assess the concentration of some heavy metals in water, soil and fish samples and the suitability of the physico-chemical parameters of the water from the selected ponds located at Kuje river bank, Idu industrial area and Lugbe in Abuja, Nigeria.

\subsection{Scope of Study}

The concentration of selected heavy metals were determined in water, soil and fish samples from three selected fish ponds in Kuje river bank, Idu industrial area and Lugbe, all located in Federal Capital Territory, Abuja. Each sample collected at four weeks intervals between May-July 2016 was analyzed in triplicate. The physic-chemical properties of the water samples were determined to ascertain its suitability for fish cultivation. A total number of 81 samples were collected and analyzed.

\subsection{Sample Collection}

\section{Sampling}

The samples were collected from each fish pond once in every four weeks between May 2016 and July 2016. A total of 4 litres each of water samples from different points at $20 \mathrm{~cm}$ depth of the pond were collected using $250 \mathrm{~mL}$ bottles which were pre-washed with $10 \%$ nitric acid and distilled water. Bottom soil/sediment samples were obtained from the same point where water samples were collected. At each point, three sediment samples were taken superficially using pre-cleaned $100 \mathrm{~mL}$, wide mouthed, disposable plastic containers and packed separately in polyethylene bags. Matured fish samples 2 in number (aged between 5-15months) from each pond were collected using a mini trapping fishing net and were killed using a ceramic knife and placed in ice box at a temperature of $4{ }^{\circ} \mathrm{C}$ before transporting to the laboratory for analysis. All Collected samples were labeled based on the location of each pond and period of collection.

\subsection{Preparation of Standard Solutions}

\section{Method Of Analysis}

Standard solutions of $\mathrm{Cu}, \mathrm{Zn}, \mathrm{Fe}, \mathrm{Cd}, \mathrm{Ni}$ and $\mathrm{Pb}$ were prepared from their salts according to ${ }^{[10]}$ procedure for Atomic absorption spectroscopy. A known $1000 \mathrm{mg} / \mathrm{L}$ concentration of the metal solution was prepared as the stock solution. Standards solution were further prepared from the stock solutions by dilution with deionized water.

\subsection{Sample Preparation}

To obtain a representative sample, composites of the fish were prepared by taking the edible tissues (fillet) of the two fish samples at each sampling site. The fish samples were oven dried at $105{ }^{\circ} \mathrm{C}$ until they reached a constant weight ${ }^{[11]}$. Each dried sample was then ground into a fine powder using porcelain mortar and pestle, and thereafter all powdered tissues were kept in desiccators prior to further chemical analysis. Soil samples were dried in an oven at $55{ }^{\circ} \mathrm{C}$ for 48 hours and fine powder was made by grinding with mortar and pestle to form a composite mixture which was stored in a polyethylene bag in a desiccator for analysis. 


\subsection{Digestion of Samples}

The ashed fish sample weighing $2.07 \mathrm{~g}$ was placed in a $250 \mathrm{~cm}^{3}$ beaker, then $5 \mathrm{~cm}^{3}$ of concentrated nitric acid $(65 \%)$ and $1 \mathrm{~cm}^{3}$ hydrogen peroxide $\mathrm{H}_{2} \mathrm{O}_{2}(30 \%)$ was added and heated on a heating mantle under a fume hood for 2 minutes until almost dry which was then cooled to a temperature of $25^{\circ} \mathrm{C}^{[11]}$. The solution was then filtered using Whatman No. 45 filter paper and diluted with deionised water to $50 \mathrm{~cm}^{3}$ and stored in polyethylene bottles. Determination of the heavy metals in the filtrate of the digested samples was achieved using an atomic absorption spectrophotometer.

The dried sediment sample weighing $2.18 \mathrm{~g}$ was placed in a $250 \mathrm{~cm}^{3}$ beaker, then $5 \mathrm{~cm}^{3}$ of concentrated nitric acid $(65 \%)$ and $1 \mathrm{~cm}^{3}$ hydrogen peroxide $\mathrm{H}_{2} \mathrm{O}_{2}(30 \%)$ were added and heated on a heating mantle under a fume hood for 2 minutes until almost dry which was then cooled to a temperature of $25^{\circ} \mathrm{C}^{[11]}$. The solution was then filtered using Whatman No. 45 filter paper and diluted with de-ionized water to $50 \mathrm{~cm}^{3}$ and stored in polyethylene bottles. Determination of the heavy metals in the filtrate of the digested samples was achieved using an atomic absorption spectrophotometer.

\subsection{Analyses of Physico-Chemical Parameters of Water Samples}

The $\mathrm{pH}$ and temperature of the water samples of Lugbe, Idu and Kuje fish ponds were measured in situ. Chloride, total dissolved solids, turbidity, electrical conductivity and total hardness were determined in the laboratory to ascertain the water quality using a using ${ }^{[12]}$ guideline.

\subsection{Metals Quantification in Water Samples}

Acid preserved water sample $(100 \mathrm{~mL})$ was taken in a beaker and $10 \mathrm{~mL}$ of nitric acid was added. It was then brought to a slow boil and evaporated on a hot plate to the lowest volume possible of $15 \mathrm{~mL}$ before precipitation occurred. Heating was continued with the addition of concentrated nitric acid till digestion was completed indicating a light coloured clear solution. Care was taken not to let sample get dried during the digestion. Beaker wall was washed with distilled water and volume was made up to $100 \mathrm{~mL}$ by adding distilled water ${ }^{[12]}$. The sample was then filtered and the filtrate was collected for analysis using Thermo Scientific SOLAAR S series atomic absorption spectrometer.

\subsection{Samples Analysis by Atomic Absorption Spectroscopy}

Atomic Absorption Spectrophotometer was used for the metal determinations which involved the use of Hollow Cathode lamp (HCL) for each of the respective elements. The analysis was carried out at the Sheda Science and Technology Complex (SHESTCO) Advanced Chemical Laboratory using Thermo Scientific SOLAAR S spectrometer. Results obtained from the spectrometry analysis were used to calculate the actual metal content in each sample using the equation below;

Metal content $(\mathrm{mg} / \mathrm{g})=\underline{\text { Concentration in solution from AAS result }(\mathrm{mg} / \mathrm{L}) \times \text { vol of dilution }(\mathrm{L})}$ Weight of sample $(\mathrm{g}) \times 1000$

\section{Tables Of Results}

Table 1: Physico-Chemical Parameters of Water Samples from Lugbe Pond

\begin{tabular}{|c|c|c|c|c|c|c|c|}
\hline Sample ID & $\begin{array}{c}\text { Temperature } \\
{ }^{\circ} \mathrm{C}\end{array}$ & $\begin{array}{c}\text { Total Hardness } \\
\mathrm{mg} / \mathrm{L}\end{array}$ & $\begin{array}{c}\text { CHLORIDE } \\
\mathrm{mg} / \mathrm{L}\end{array}$ & $\mathrm{pH}$ & $\begin{array}{c}\text { CONDUCTIVITY } \\
\mu \mathrm{S}\end{array}$ & $\begin{array}{c}\text { TURBIDITY } \\
\text { FTU }\end{array}$ & TDS mg/L \\
\hline LB1 W & 28.00 & 66.00 & 0.042 & 7.04 & 481.00 & 1000.00 & 489.00 \\
\hline LB2 W & 27.00 & 26.00 & 0.062 & 6.20 & 374.00 & 1000.00 & 226.00 \\
\hline LB3W & 26.00 & 30.00 & 0.060 & 6.33 & 388.00 & 980.00 & 300.00 \\
\hline Mean LW & $27.00 \pm 0.81$ & $40.67 \pm 17.98$ & $0.055 \pm 0.01$ & $6.53 \pm 0.37$ & $414.33 \pm 47.48$ & $993.33 \pm 9.43$ & $338.33 \pm 110.74$ \\
\hline
\end{tabular}

Table 2: Physico-Chemical Parameters of Water samples from Idu Pond

\begin{tabular}{|c|c|c|c|c|c|c|c|}
\hline $\begin{array}{c}\text { Sample } \\
\text { ID }\end{array}$ & $\begin{array}{c}\text { Temperature } \\
{ }^{\circ} \mathrm{C}\end{array}$ & $\begin{array}{c}\text { Total Hardness } \\
\mathrm{mg} / \mathrm{L}\end{array}$ & $\begin{array}{c}\text { CHLORIDE } \\
\mathrm{mg} / \mathrm{L}\end{array}$ & $\mathrm{pH}$ & $\begin{array}{c}\text { CONDUCTIVITY } \\
\mu \mathrm{S}\end{array}$ & $\begin{array}{c}\text { TURBIDITY } \\
\text { FTU }\end{array}$ & TDS mg/L \\
\hline IB1 W & 30.00 & 60.60 & 0.028 & 7.11 & 710.00 & 78.57 & 428.00 \\
\hline IB2 W & 28.00 & 46.00 & 0.062 & 6.28 & 702.00 & 178.00 & 423.00 \\
\hline IB3W & 27.00 & 48.00 & 0.058 & 6.50 & 689.00 & 120.00 & 420.00 \\
\hline Mean IW & $28.33 \pm 1.25$ & $51.53 \pm 6.46$ & $0.049 \pm 0.02$ & $6.63 \pm 0.35$ & $700.33 \pm 8.65$ & $125.52 \pm 40.78$ & $423.67 \pm 3.30$ \\
\hline
\end{tabular}

Table 3: Physico-Chemical Parameters of Water samples from Kuje Pond

\begin{tabular}{|l|c|c|c|c|c|c|c|}
\hline $\begin{array}{l}\text { Sample } \\
\mathrm{ID}\end{array}$ & $\begin{array}{c}\text { Temperature } \\
{ }^{\circ} \mathrm{C}\end{array}$ & $\begin{array}{c}\text { Total Hardness } \\
\mathrm{mg} / \mathrm{L}\end{array}$ & $\begin{array}{c}\text { CHLORIDE } \\
\mathrm{mg} / \mathrm{L}\end{array}$ & $\mathrm{pH}$ & $\begin{array}{c}\text { CONDUCTIVITY } \\
\mu \mathrm{S}\end{array}$ & $\begin{array}{c}\text { TURBIDITY } \\
\text { FTU }\end{array}$ & TDS mg/L \\
\hline $\mathrm{KB} 1 \mathrm{~W}$ & 28.00 & 38.00 & 0.017 & 7.20 & 588.00 & 946.00 & 290.00 \\
\hline $\mathrm{KB} 2 \mathrm{~W}$ & 29.00 & 26.00 & 0.014 & 6.50 & 521.00 & 1000.00 & 312.00 \\
\hline KB3W & 26.00 & 28.00 & 0.012 & 6.68 & 500.00 & 1000.00 & 301.00 \\
\hline Mean KW & $27.67 \pm 1.25$ & $30.67 \pm 5.25$ & $0.014 \pm 0.00$ & $6.79 \pm 0.29$ & $536.33 \pm 37.52$ & $982.00 \pm 25.45$ & $301.00 \pm 8.98$ \\
\hline
\end{tabular}

Where: L - Lugbe, I - Idu, K- Kuje, B - Batch, W - Water 
(Tables 1, 2, and 3) showed that the highest recorded temperature was $30^{\circ} \mathrm{C}$ in Kuje and the lowest 26 ${ }^{\circ} \mathrm{C}$ in Idu. Increased temperature causes an increase in the metabolic activity of the fish while reducing the dissolved oxygen content in the system ${ }^{[13]}$. The total hardness was highest in May at $66 \mathrm{mg} / \mathrm{L}$ in Lugbe when the volume of rainfall was low and lowest in July at $30 \mathrm{mg} / \mathrm{L}$ when the volume of rainfall was much at the same location. In Idu, it followed the same pattern; the total hardness was $60.6 \mathrm{mg} / \mathrm{L}$ in May and $48.0 \mathrm{mg} / \mathrm{L}$ in July. The same was for Kuje, the total hardness was $38 \mathrm{mg} / \mathrm{L}$ in May and 28mg/L in July. Hardness is a vital factor in maintaining good pond equilibrium. Chloride concentrations are minimal in all the three locations with values between $0.012-0.062 \mathrm{mg} / \mathrm{L}$, which fell below the WHO permissible limit of $250 \mathrm{mg} / \mathrm{L}$. The $\mathrm{pH}$ of the water in Lugbe ranges from 6.20-7.04, 6.28-7.11 for Idu and 6.50-7.20 for Kuje. The pH values obtained were consistent with the findings of ${ }^{[14]}$ and ${ }^{[15]}$. The electrical conductivity (EC) of the water in Lugbe ranges from 374-481 $\mu \mathrm{S} / \mathrm{cm}$ and that of Kuje, $500-588 \mu \mathrm{S} / \mathrm{cm}$. The EC of water in Idu ranges from $689-710 \mu \mathrm{S} / \mathrm{cm}$ were above the WHO acceptable limit. The measured turbidity of the water in Lugbe and Kuje of $>1000$ FTU were above the permissible limit set by WHO of $1000 \mathrm{FTU}^{[16]}$. The water turbidity levels recorded at Idu were between 78.57178.00 FTU which fell within the WHO permissible. The total dissolved solids (TDS) for Lugbe water ranges from $226-489 \mathrm{mg} / \mathrm{L}$, that of Kuje ranges from $290-312 \mathrm{mg} / \mathrm{L}$ and that of Idu $420-428 \mathrm{mg} / \mathrm{L}$ all fell within the EPA permissible limit of $500 \mathrm{mg} / \mathrm{L}$.

Table 4: Heavy Metals contents in Water from Lugbe Fish Pond

\begin{tabular}{|c|c|c|c|c|c|c|}
\hline Sample ID & Fe & Zn & Cd & Ni & Pb & Cu \\
\hline LW mg/L & 0.6640 & 0.0155 & 0.0409 & 0.5583 & 0.2974 & 0.0216 \\
\hline LS mg/g & 0.5765 & 0.0125 & 0.0003 & 0.0033 & 0.0048 \\
\hline LF mg/g & 0.0153 & 0.0198 & 0.0003 & 0.0218 & 0.0063 \\
\hline
\end{tabular}

LW - Mean of Water Sample $\quad$ LS - Mean of Soil Samples $\quad$ LF - Mean of Fish Samples

For Lugbe, Table 4 shows the metal concentrations was in the order $\mathrm{Fe}>\mathrm{Ni}>\mathrm{Pb}>\mathrm{Cd}>\mathrm{Cu}>\mathrm{Zn}$ in water. Iron has the highest concentration of $0.6640 \mathrm{mg} / \mathrm{L}$ than other metals present in the water which could be as a result of corrosion of the iron or steel borehole casing and the geology of the location of the pond. The concentration of zinc was least at $0.0216 \mathrm{mg} / \mathrm{g}$ in the water sample. Lead was found to be highest in the water sample at $0.2974 \mathrm{mg} / \mathrm{g}$; Lead is found easily in pond water where lead pipes are used to flow water into and out of the pond. The hardness of the water is a major factor of how much lead will dissolve in the surface water ${ }^{[17]}$. The soil samples had more of the iron concentration at an average of $0.5765 \mathrm{mg} / \mathrm{g}$; this may be due to the rust in the inlet pipe used in supplying water to the pond and subsequent absorption by the soil. Cadmium was present in least concentration of $0.0003 \mathrm{mg} / \mathrm{g}$ in the soil samples. The fish samples had more concentration of nickel at $0.0218 \mathrm{mg} / \mathrm{g}$; the level of the nickel may be attributed to its uptake from the water by the fish. Higher level of zinc at $0.0198 \mathrm{mg} / \mathrm{g}$ in the fish sample as against the water and soil could suggest that the zinc accumulation came from the foods taken by the fish. The nickel, iron, and cadmium, iron, lead, copper and zinc concentrations in water, soil and fish in the Lugbe fish pond did not exceed the FAO/WHO maximum permissible limit.

Table 5: Mean Concentrations of Water, Soil and Fish Samples from Idu Fish Pond

\begin{tabular}{|c|c|c|c|c|c|c|}
\hline Sample ID & Fe & Zn & Cd & Ni & Pb & Cu \\
\hline LBIW mg/L & 0.0245 & 0.0191 & 0.0126 & 0.0243 & 0.1323 \\
\hline LB2W mg/L & 0.5496 & 0.0111 & 0.0000 & 0.0045 & 0.0033 \\
\hline LB3W mg/L & 0.0253 & 0.0070 & 0.0000 & 0.0006 & 0.0015 & 0.0060 \\
\hline
\end{tabular}

IW - Mean of water sample IS - Mean of Soil samples IF - mean of fish samples

From Table 5, the concentration of heavy metals was in the order of $\mathrm{Cu}>\mathrm{Fe}>\mathrm{Ni}>\mathrm{Zn}>\mathrm{Pb}>\mathrm{Cd}$ in water. Copper had the highest concentration of $0.0417 \mathrm{mg} / \mathrm{L}$ in water. The concentration of $\mathrm{Pb}$ in water was 0.1323 $\mathrm{mg} / \mathrm{L}$. A previous study carried out in England showed that high level of lead in some pond water can be attributed to industrial and agricultural discharge ${ }^{[9]}$. Lead is a cumulative toxin and its other sources include automobile exhaust fumes, used dry-cell batteries, from sewage affluent, run off wastes and atmospheric deposition ${ }^{[9]}$. Lead concentration at $0.1323 \mathrm{mg} / \mathrm{l}$ in the water was above the WHO standard limit of $0.01 \mathrm{mg} / \mathrm{g}$. The high level of iron $(0.5496 \mathrm{mg} / \mathrm{g})$ in soil as against that in water and fish is attributed to the industrial and construction activities around the pond. The Soil samples in Idu had less of the metal concentrations compared to that found in the water samples. Iron has the highest concentration of $0.5496 \mathrm{mg} / \mathrm{g}$, which could be as a result of its general abundance in soil ${ }^{[17]}$. The average $\mathrm{pH}$ of the water above the soil is slightly acidic hence a likely increase in the availability of iron in the soil ${ }^{[9]}$. The metal concentrations in the fish samples are in the order $\mathrm{Cu}>\mathrm{Fe}>\mathrm{Zn}>\mathrm{Ni}>\mathrm{Pb}>\mathrm{Cd}$. The mean average copper concentration in fish was found to be $0.0386 \mathrm{mg} / \mathrm{g}$ less than that found in soil and water likely as a result less absorption of the metal by the fish. The mean concentration of copper in the fish samples was $0.0386 \mathrm{mg} / \mathrm{g}$ which fell below the permissible limit set by WHO of $1.0 \mathrm{mg} / \mathrm{g}$. The varying concentrations of the metals found in the fish depend on various factors such as feeding behavior and temperature. 
Evaluation Of Concentration Of Some Heavy Metals In Water, Soil, And Fish From Ponds In Lugbe,

Table 6: Mean Concentrations for Water, Soil and Fish Samples for Kuje Fish Pond

\begin{tabular}{|c|c|c|c|c|c|c|}
\hline Sample ID & Fe & Zn & Cd & Ni & Pb & Cu \\
\hline $\mathrm{KW} \mathrm{mg/L}$ & 3.3522 & 0.0473 & 0.0121 & 0.01234 & 0.3939 & 0.0000 \\
\hline $\mathrm{KS} \mathrm{mg/g}$ & 0.6862 & 0.0044 & 0.0000 & 0.0070 & 0.0011 & 0.0000 \\
\hline $\mathrm{KF} \mathrm{mg/g}$ & 0.0102 & 0.0067 & 0.0000 & 0.0015 & 0.0024 & 0.0000 \\
\hline
\end{tabular}

KW - Mean of water sample $\quad$ KS - Mean of Soil samples $\quad$ KF - mean of fish samples

From table 6 the concentration of iron in Kuje water of $3.3522 \mathrm{mg} / \mathrm{L}$ was far above the WHO recommended limit of $0.3 \mathrm{mg} / \mathrm{L}$. The concentration of zinc is higher in the water at $0.0473 \mathrm{mg} / \mathrm{L}$ which is below the acceptable value of WHO value of $3.0 \mathrm{mg} / \mathrm{L}^{[16]}$. The concentration of $0.6862 \mathrm{mg} / \mathrm{g}$ for the soil is also above the WHO limit. The surrounding environment of the pond is agricultural farmlands whereby the high level can be attributed to wash off from chemicals and fertilizers from the farmland and accumulation of the iron in soil. The concentration of lead in water $0.3939 \mathrm{mg} / \mathrm{L}$ is above the WHO acceptable limit. Lead could have entered the pond in different forms of salt. Lead and lead (II) salts and organic lead compounds are considered ecotoxicologically harmful ${ }^{[9]}$. Other forms of lead could be lead acetate, lead oxide, lead nitrate, and lead carbonate that entered the surface water. Increase in the average concentration of lead in the plants found in the fish pond can lead to the transportation of the lead into the water body. Plants may take up high levels of lead up to $500 \mathrm{ppm}$ from soils ${ }^{[18]}$. The metal concentrations in the soil is in the order $\mathrm{Fe}>\mathrm{Ni}>\mathrm{Zn}>\mathrm{Pb}>\mathrm{cd}>\mathrm{Cu}$. Iron was found to be $0.6862 \mathrm{mg} / \mathrm{g}$ while cadmium and copper were not detected in the soil samples. Zinc was found to be $0.0044 \mathrm{mg} / \mathrm{g}$ which is consistent with the work done by ${ }^{[17]}$. The average iron concentration in the fish was found to be $0.0102 \mathrm{mg} / \mathrm{g}$ which was below the WHO limit of $0.1 \mathrm{mg} / \mathrm{g}$, the concentration of the iron in the fish is consistent with those reported in USA ${ }^{[15]}$ and those by ${ }^{[19]}$ in Egypt. The concentration of lead in fish at $0.0024 \mathrm{mg} / \mathrm{g}$ shows that the lead could have been transported into the fish through the gills of the fish. There was no cadmium and copper contamination detected in fish.

\section{Conclusion}

The results of this study revealed that consuming fish from the ponds in Lugbe, Idu and Kuje may be harmful to consumers in the long-term because some observed values of heavy metals in the water samples and soil samples were above the permissible limits issued by FAO/WHO and can easily be absorbed by the fish considering the strong correlation among all the sample unless proper actions are taken to mitigate the presence of the heavy metals found in the samples.

\section{References}

[1] Nigerian Observer News, Archive. October, 2014. Fish Consumption in Nigeria

[2] M. D. Onyango, S. Wandili, R. Kakai and E. N. Waindi. Isolation of Salmonella and Shigella from fish harvested from Winam gulf of Lake Victoria. Journal of Information in Developing Countries, 3(2), 2009, 99-104.

[3] C. J. Ida. Heavy Metals in Suchindramkulam (A Lentic Water Body) of Kanyakumari District, Tamil Nadu, India. Journal of Tropical and Experimental Biology 8(3 and 4): 2012, 141-145

[4] O. J. Egbere, A. Kadir, T. Oyero, K. Steve, O. Odewumi and H. Zakari. Bacteriological Quality of Catfish in Jos Metropolis, Nigeria. International Journal of Bioscience, 5 (2), 2008, 95-10.

[5] P. C. Howgate, C. Lima dos Santos and Z. H. Shebiadeh. Aquaculture Products: Quality, Safety, Marketing and Trade. Proceedings of the Conference on Aquaculture in the Third Millennium, (Bangkok, Thailand, 2001). 220-225.

[6] M. Z. Vosyliene, N. Kazlauskiene and G. Svecevicius. Effect of a Heavy Metal Model Mixture on Biological Parameters of Rainbow Trout (Oncorhynchus mykiss). Environmental Science and Pollution Research. 10: 2003, $103-107$.

[7] O. M. Olowosegun, T. Olowosegun and H. Mohammed (2005). A Review on the Effects of Water Pollution on Fish and the Fishing Industry of Nigeria. 2005 FISON Conference Proceedings, Port Harcourt, Nigeria. 423-428.

[8] F. Yilmaz, N. Ozdemir, Demirak and A. L. Tuna. Heavy Metal Levels in Two Fish Species Leuciscus cephalus and Lepomis gibbosus. Food Chemical, 100 (2), 2007, 830-835.

[9] J. Mason Qualitative Researching (2nd edition). (London, 2002) 30-59.

[10] APHA, American Water Works Association - AWWA and Water Pollution Control Federation -WPCF, Standard Methods for the Examination of Water and Arsenic, Cadmium, Mercury and Lead in Common Foods and Estimated Daily Intake by Children Associated Problems in Pakistan. Journal of Science, Technology and Development.15, 2005, 41-50.

[11] J. Jackson. UNEP/WHO/UNESCO/WMO Programme on Global Water Quality Monitor and Assessment. GEMS/Water Operational Guide. Chapter VI. Biological Monitoring. (London, 1992). 6pp.

[12] C. S. Mutuku. Association of Heavy Metal Tolerance with Multiple Antibiotic Resistance in Bacteria Isolated from Wetlands of Lake Victoria Basin Kenya. MSc. Unpublished Thesis, Kenyatta University, 2010.

[13] M. Afzal, A. Rab, N. Akhtar, M. F. Khan, A. Barlas, and, M. Qayyum. Effect of Organic and Inorganic Fertilizers on the Growth Performance of Bighead Carp (Aristichthys nobilis) in Polyculture System. International Journal of Agriculture and Biology, 9 (6): 2000, 931-933

[14] A. V. Ayanwale, M. A. Minnin and K. Olayemi. Physico-Chemical Properties of Selected Fish Ponds in Nigeria: Implications for Artificial Fish Culture. Web medical Central Biology, 3, 2012, (10).

[15] K. Silapajarn, C. E. Boyd and O. Silapajarn. (2004). Physical and Chemical Characteristics of Pond Water and Bottom Soil in Channel Catfish Ponds in west-central Alabama.

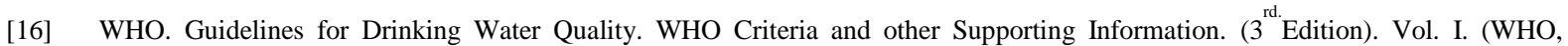
Geneva, 2006). 145-196.

[17] Lenntech (2014). Periodic Elements. http://www.lenntech.com/periodic/elements/.htm (Accessed October $\left.{ }^{\text {th }}, 2014\right)$.

[18] M. Witeska and B. Jezierska. Metal Toxicity to Fish: Reviews in Fish Biology and Fisheries. 11: 279-280, 2001

[19] M. S. Samir and M. S. Ibrahim (2008). Assessment of Heavy Metals Pollution in Water and Sediments and their Effect on Oreochromis niloticus in the Northern Delta Lakes, Egypt. 8th International Symposium on Tilapia in Aquaculture 